\title{
Solidarity Action in Global Labor Networks. Four Cases of Workplace Organizing at Foreign Affiliates in the Global South
}

I Peter Wad'

Associate professor, Department of Intercultural Communication and Management, Copenhagen Business School, Denmark

\begin{abstract}
Globalization transforms workforces of transnational corporation from predominantly home countrydominated workforces into foreign-dominated, multinational workforces. Thus, the national grounding of trade unions as the key form of labor organizing is challenged by new multinational compositions and cross-border relocations of corporate employment affecting working conditions of employees and trade unions in local places. We assume that economic globalization is characterized by expanding global corporate network of vertically and horizontally integrated (equity-based) and disintegrated (nonequity-based) value chains. We also assume that globalization can both impede and enable labor empowerment. Based on these premises the key question is, how can labor leverage effective power against management in global corporate networks? This question is split into two subquestions: a) How can labor theoretically reorganize from national unions and industrial relations institutions into global labor networks that allow prolabor improvement in global workplaces? b) How and why has labor in a globalized economy secured the core International Labor Organization (ILO) international labor right to organize companies and conduct collective bargaining? The Global Labor Network perspective is adopted as an analytical framework. Empirically, a comparative case methodology is applied comprising four more or less successful industrial disputes where labor achieved the right to organize and undertake collective bargaining. The disputes took place in affiliated factories of foreign transnational corporations located in Malaysia, the Philippines, Sri Lanka, and Turkey. The conclusion is that the combination of global labor capabilities and global labor strategizing must generate strategic labor power that adequately matches the weaknesses of the counterpart's global corporate network in order to achieve prolabor outcomes. The most efficient solidarity action was leveraged by a cross-border alliance of workplace collectives, national industrial unions, and a global union federation using global framework agreements (GFAs) with key customers of the employer. The least efficient campaign relied primarily on domestic developing country state institutions supported by a foreign labor nongovernmental organization (NGO).
\end{abstract}

\section{KEY WORDS}

Global labor network / industrial dispute / international labor rights / labor campaign / Malaysia I the Philippines / Sri Lanka / transnational corporations / Turkey

\section{Introduction}

ith increasing internationalization and globalization of production, trade, financing, and information flows, corporations and workplaces are becoming more and more complex and 'denationalized.' The workforce of the most internationalized transnational corporations (TNCs) is overwhelmingly 'foreign' relative to the home of

\footnotetext{
${ }^{1}$ E-mail: pw.ikl@cbs.dk.
} 
the headquarters and its traditional domestic base. The most internationalized multinational companies employed more people abroad than at home in the 2000s compared with 1995 (UNCTAD various years). According to industry, the vast oil TNCs seemed to have reached the foreign employment ceiling in the 2000s while most giant motor vehicle TNCs have steadily increased their offshore employment base over time. Toyota Motor Corp. reached a global workforce with nearly 50 percent foreign employees in 2000 (calculated from Shimizu 2003, 135, 142). Countrywise, the same trend is observed. For example, Danish firms with subsidiaries abroad employ nearly 1.27 million offshore in 2011 and foreign TNC subsidiaries employed more than 270,000 employees in Denmark (2010). With a total Danish private labor force of around 1.3 million employees in 2011, Danish firms employ nearly the same amount of people abroad as at home. In addition, $20 \%$ of Danish private sector employees are employed by foreign companies (Denmark's Statistics 2013).

The trend of transnationalized corporate workforces challenges once again the nationally constituted trade unions, whether they are craft-, industry-, or occupation-based organizations. These unions cannot operate effectively and efficiently within national borders when their counterpart of employers and corporate managers operate crossborder businesses. Management reconfigures their global value chains in line with perceived comparative and competitive advantages and captures surplus value wherever they prefer, e.g., in tax havens. Thus, contemporary corporate offshoring and outsourcing of production and service activities question the bargaining power of nationally constituted unions. This transformation of corporate employment adds to the ongoing weakening of organized labor in terms of declining union density, erosion of unions' power at the labor market and workplaces, and their political salience. No wonder that the wage share of functional income distribution has declined in advanced countries as well as developing countries in recent years (Stockhammer 2012).

We assume that economic globalization is characterized by expanding global corporate network of vertically and horizontally integrated (equity-based) and disintegrated (nonequity-based) value chains (Dicken 2011; UNCTAD 2013). We also assume that globalization can both impede and enable labor empowerment (Wills 1998). The key question is the following: How can labor leverage effective power against management in global corporate networks? This question is split into two subquestions: a) How can labor theoretically reorganize from national unions and industrial relations institutions into global labor networks that allow prolabor improvement in global workplaces? b) How and why has labor in a globalized economy secured the core international labor right to organize companies and conduct collective bargaining?

Regarding the first subquestion, our claim is that in a context of expanding global corporate networks governed by TNCs, enterprise-based labor networking across borders is vital to effectuate labor improvements in global industries. The reason is that TNCs govern their global reach, mobility and value creation, distribution and capture both in equity-based business networks and in nonequity-based transactions. Labor must therefore be able to organize intra-corporate as well as inter- and extra-corporate cross-border networks that can reregulate the flow of values in order to obtain an acceptable social share of collectively generated value added. Such global labor networks can potentially identify and pressure TNCs on their weak positions in order to engage decision-makers in collective negotiations and problem solving. But intra-corporate labor networks alone are probably not sufficient to secure prolabor outcomes of industrial disputes. 
The success or failure of global labor networks is also tightly knit with national industrial relations legislation and administration. Trade unions are mostly constituted as national organizations within industry, craft, or occupational labor market segment, with the exception of Japan, South Korea, and Chile among Organisation for Economic Cooperation and Development (OECD) countries today. Restructuring nation-based unions into global labor networks of trade unions and worker collectives may cause union leaders to feel loss of 'sovereignty', and rank-and-file employees may lose sense of trade unionism. Employees of TNCs may not understand or care about the global foundation and external vulnerability of their local workplaces.

Regarding the second subquestion, we ask for an empirical analysis of the actual distribution and change of TNC compliance with the international labor right to organize and collectively bargain agreements with employers. This right is considered a core labor right (Convention 98) by the ILO. It is a so-called 'enabling right' because it allows building and sustaining workplace labor power and thus enables marginalized labor to take part in the intra-corporate bargaining over collectively generated values. To answer the subquestion a comparative case methodology is applied analyzing four more or less successful industrial disputes and labor campaigns about the right to organize and undertake collective bargaining from a worker collective perspective. The disputes took place at affiliated factories of foreign TNCs in Malaysia (Wad 2007, 2013), the Philippines (Wad \& Tackney 2011), Sri Lanka (Egels-Zandén \& Hyllman 2006, 2007), and Turkey (IndustriALL 2013). Three of the case studies are based on empirical evidence delivered by the author and other social researchers while the fourth case study is known from the union press only and is thus based on partial evidence.

The article proceeds in the following way. The next section outlines our theoretical perspective capturing the problem area of corporate globalization transcending national borders of trade union power and how trade unions can bridge the gap between TNC's global operations and trade unions' nationally confined collective actions. Then, the four cases are presented outlining the key features of the industrial disputes between Northern TNCs and Southern trade unions. The case presentations are summarized before they are compared and the findings of the multiple case study are discussed in order to explain why some concerted labor efforts succeed and others fail. This enables us to identify the types of global labor networks in context that are necessary and/or sufficient to conduct effective cross-border campaigns making TNCs to comply with ILO Convention 98. The last section concludes the article and outlines limitations of the analysis and options for future research.

\section{Labor organizing in global production networks: a theoretical outline}

The key assumption about labor organizing within and across global production networks is that such global labor networks have to comprehend several levels at the same time and be flexible enough to enable upscaling and downscaling according to the situation. Thus, labor action targeting local problems in global production networks must at the same time involve local union capabilities and mobilize global union and nonunion allies targeting and pressuring corporate headquarters where the final decisions are made and sustained.

Whether global labor networks of global unions, national unions, and workplace union activists are strong enough to enter and conclude agreements with TNCs about 
industrial disputes, for example, over international labor rights, is assumed to be a matter of strategic analysis, union capacity, and adequate collective action (campaigning) based on union or multistakeholder coalitions. Reviewing literatures of Global Value Chains, Global Production Networks, and Labor Geography and integrating key understandings from the Union Strategic Corporate Analysis (Bronfenbrenner 2007; Juravich 2007; Juravich \& Bronfenbrenner 1999, 2003) and the Strategic Choice Framework (Weil 2005), the author (Wad 2013) construed a Global Labor Network perspective. The aim was to analyze the relationship between union strategic corporate campaigns and unions' capabilities to implement them effectively, thus integrating existing approaches and enable union strategic analysis beyond the context of the US labor market crossing the divide of Global North and Global South.

The Global Labor Network approach relies on two analytic components for effective global collective action by labor: a) the labor strategy for corporate industrial relations transformation including the deliberately designed and/or practiced campaign to accomplish the specific labor objectives, and b) the capability of the global labor network to pressure vulnerable nodes and relations of the global corporation to the extent that corporate headquarters and local management give in, negotiate, and conclude an agreement that settles the dispute and accomplishes the objective of the labor campaign.

The core concept, labor network, is defined as the more or less informal or formal, temporary or institutionalized relationships between, on the one hand, employees in workplace collectives or labor organizations and, on the other hand, other labor groups and/or nonlabor groups that align (in solidarity) with the cause of the focal labor actor. The concept of global labor networks comprises cross-border labor networks bridging the divide of Global North and Global South. Such networks can be described in terms of depth (form and intensity of interaction), scope (social domains or arenas of action), and geographical scale (moving vertically from workplace to local, regional, national, macroregional, and global union networks, or horizontally at the same vertical level across space). Labor strategy is a more or less deliberate articulation (discourse) of labor agency defined by its vision, intent, or target of the focal labor group, combined with an outline of the means and methods to be applied. Over time, a strategy evolves through an ongoing learning process of operational choices informed by conceived strategy and experiences while adapting means and eventual ends to the perceived and changing resources and capabilities available. Thus, the process of strategizing involves much more than just executing a strategic blue print. Formulating and executing such a strategy successfully depends on the capacity of the labor collective, including its competences, resources, organization, and networks.

To be effective a strategy must be translated into a campaign, or defined as a project or a series of collective actions that have an effect relative to its objectives as well as a wider impact on the collective and its environment. To be efficient, the strategy must do so in a relatively shorter time using less resources. A successful campaign accomplishes the focal objectives and can simultaneously improve (or weaken) labor capacity and capability (power) and/or the employment conditions of union members (employee benefits) depending on the objectives of the campaign and the resources mobilized, enhanced, or destroyed. In sum, the concept of labor agency (power in action) is defined as the capability of labor with institutional and value chain leverage to target and promote corporate decision-making in favor of the objectives of the labor campaign, for 
example, empowerment of labor through management recognition of the employees' chosen union.

This way of theorizing global labor agency assumes that the core structural context of the focal labor agency (object of research) is the global corporate network embedding the management-labor dispute at the microlevel (workplace). A global corporate network can be composed of several global value chains that can be productively related (vertically connected) or unrelated (horizontally) in terms of global value chains but linked through equity, contract, or information. Understood in terms of process, the focal labor agency will be spatially fixed in place and evolve in scale and time at and across single or multiple levels of workplace, locale, province, nation, region, and world, scaling up, scaling down, or rescaling horizontally or vertically.

The overarching concept of strategic power is defined by the combined labor capability and strategic opportunity. Labor capability is the available organizational or network capacity and competence and it may turn into a dynamic capability with learning. Strategic opportunity is defined by the weaknesses and vulnerabilities of corporate power due to key institutional and value chain relations that can affect centers of profitability or growth negatively or reduce corporate reputation and thereby impact corporate headquarters to make prolabor decisions. The overall strategic power of the global labor network is the confluence of all these mechanisms of influence enacted in time and place within the domain of the global labor networks, which elicits the ultimate decision resolving the industrial dispute in favor of labor objectives. Therefore, chains of equity, or capital ownership and control in other words, and management hierarchy and leadership are extremely important for global labor agency. Yet, this dimension has often been marginalized in global value chain analysis and especially in buyer-driven global value chains where inter-firm transactions are governed through nonequity forms of power, for example, certification and quality standards. But it is a pertinent issue known as supply chain responsibility.

Global corporations are often conglomerates or business groups like Danish APM-Maersk and they bundle related or unrelated global value chains, forming global corporate networks. New global value chain options for labor influence may be structurally available outside the global value chain where the focal workplace/local company is located due to global corporate ownership or chains of capital. Strategic labor opportunities may also change over time, for example, due to mergers or acquisitions of corporate assets which may reposition the local company and workplace from a nongrowth center to a growth center.

The Global Labor Network analysis aims to explain the effects and impact of the labor campaign in terms of campaign characteristics and the total strategic power exercised during the campaign. Following a Union Strategic Corporate Analysis (Juravich 2007) one proposition is that comprehensive campaigns have greater likelihood of success than noncomprehensive or traditional campaigns. The argument is that such campaigns against TNCs are more effective because they target and hit nodes of the TNC network that affect profit or growth centers negatively, compared with traditional campaign of direct action against the employer and company of the focal worker collective. Following the Strategic Choice Framework (Weil 2005) a second proposition reads that adequate adjustment of union strategy and organizational tactics to union capacity over time will increase the probability of success. Following global value chain and global production network thinking (Coe et al. 2008; Cumbers et al. 2008; Riisgaard 2009), a 
third proposition is that global labor campaigns will be more effective when the domain of the global labor network adequately matches to strike most vulnerable points within the global power network that affects the lead firms governing the global value chain primarily through corporate standards. Following Labor Geography thinking (Castree 2007) a fourth proposition is that scaling up and down horizontally and vertically is critical to overcome resistance by global capital and that labor scaling tactics depend on sustained local and workplace labor interest, articulation, understanding, and organizational capability. A fifth proposition and key to the Global Labor Network perspective is that global labor campaigns succeed to the degree that the strategic power and applied network capabilities are coherently and adequately matching the power of the corporate network of the capital counterpart. Thus, this proposition integrates the first four propositions in the strategic power perspective of the fifth proposition. A corollary to the fifth proposition is that cross-border workplace labor networking is necessary to achieve an effective power match with management of corporations with transnationalized workforces.

In sum, the rationale of the Global Labor Network framework can be depicted in a simplified manner leaving out feedback effects except the response of corporate management to the labor claim (Figure 1).

Figure I: Dynamics of Global Labor Network (arrows illustrate select flows of potential influence).

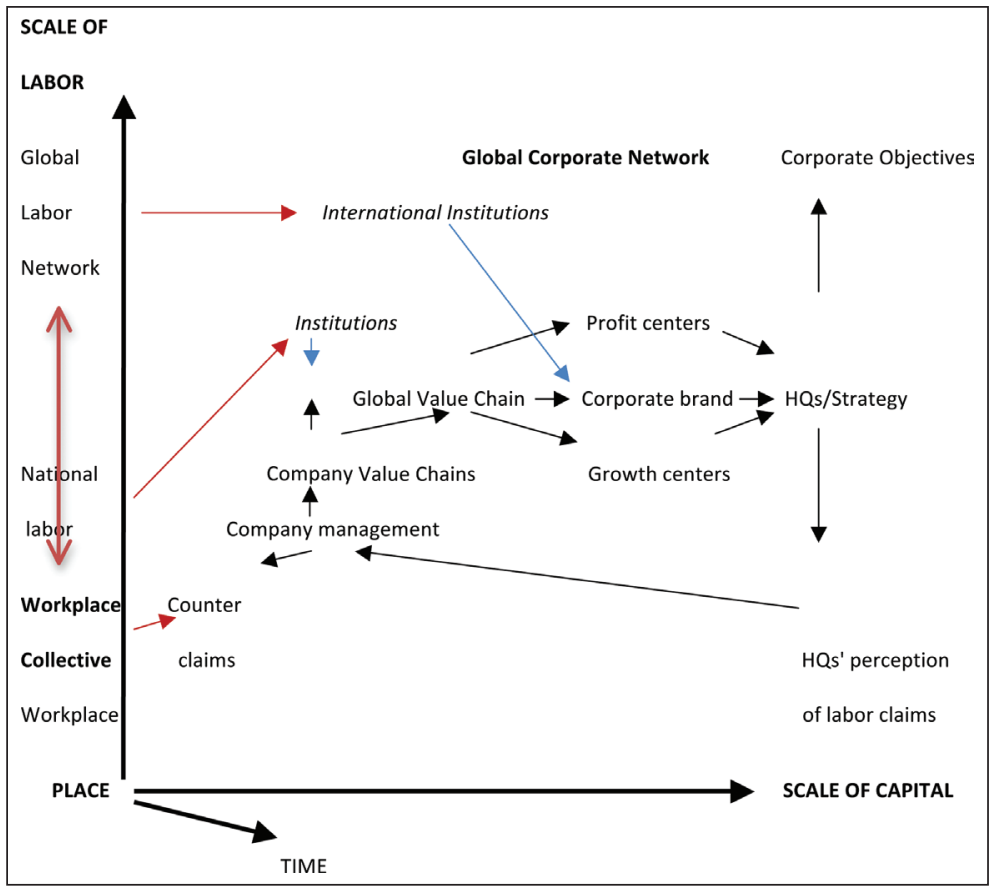

Bold arrows = dimensions of framework structure anchored in space and time and composed of social mechanisms linking labor, capital, and institutions. Red arrows = labor-driven processes. Blue arrows: institution-linked processes. Black arrows $=$ capital-linked processes. 
Explanatory note: The analysis is focused on a specific labor-management dispute that is located in time and space in a particular workplace embedded in a structure of global corporate, labor, and societal networks and institutions. This structure comprises a set of social mechanisms that can be triggered or blocked by, for example, managerial and labor actors. An example: An industrial dispute begins with contradicting claims from a worker collective and management, which makes the labor actor sending its claim to the local industrial relations institution. Approached by the institution the management rejects the claim and the institution accepts it. The labor actor calls upon the judiciary system of industrial courts and civilian courts. Moreover, along the way the labor actor contacts foreign labor actors in the country where the company's mother corporation is headquartered (HQs). The foreign labor ally takes the case to an international organization which makes the case public in the home country of the corporation and threatens its reputation. The top management of the corporation decides to comply with the claim of the local workers' collective in the affiliated company acknowledging that this company is a core profit center within the corporation's global value chain.

\section{Comparative cases of industrial disputes}

The analysis of the four industrial disputes entails a description of the key features of the industrial conflict, including the (work)place of the labor-management contest (country of focal workplace), local labor and capital actors of the workplace, substance of the dispute (labor rights suppressed), ultimate corporate decision maker (corporate HQs), labor campaign (degree of comprehensiveness), and outcome of the campaign (success or failure obtaining key labor demands). In order to compare 'apple with apple,' the industrial disputes are all about the (managerially denied) labor right to organize and collective bargaining at a specific foreign-controlled workplace in a developing country. Moreover, most of the cases are clear success stories, and the exception can be interpreted as a failure or a success depending on the viewpoint taken. All cases involve cross-border campaigning, but otherwise the cases and their context vary in several ways, for example, in Industrial Relations context, industrial activity, organizational structure of labor actors, global labor networks, state and nonstate institutions mobilized by labor campaign, etc. Thus, the design of the comparison aims following the logic of the 'most different systems' design (Pennings et al. 1999; Wad 2000), identifying (unique) patterns of similarity between type of labor campaigning and contexts (independent factors) and similar outcomes (dependent factor) while keeping options open for deeper mechanisms mediating 'global labor network' capability and strategic power into global labor practices and results. In practice, the 'method of concomitant variation' was applied because the quality of the dependent and independent factors varied although the dependent outcome could be defined as a labor success because the employer complied to the labor claim for unionizing and collective negotiations. While the most different system's approach lacks the opportunity to compare 'similar patterns' (experimental cases) with 'different patterns' (control cases), this is partly possible with the design of 'concomitant variation.' Yet, the comparison concerns degrees of 'campaign success' and degrees of 'campaign comprehensiveness,' and it misses out on strict cases of campaign failure and on prolabor success with traditional campaigning (counterfactual cases). Finally, we follow a research approach of critical 
realist retroduction aiming for theory development of Global Labor Networking through comparing, contrasting, adjustment, and elaboration of theory and empirical evidence acknowledging that causality is attributed by theoretical reasons, not inductively inferred from experimental experience (Wad 2012b).

Recalling our theory the argument is that an effective global labor strategy (global comprehensive labor campaign) must trigger social mechanisms that put pressure on TNC HQs through its global production network of global value chains and institutional linkages to the point where the corporate HQs give in to labor demands. How do our cases of industrial dispute and labor campaigning from the Philippines, Malaysia, Sri Lanka, and Turkey fit our Global Labor Network theory? Given that the two cases from Malaysia and Sri Lanka reflecting semicomprehensive campaigns are taken to be clear successes, the evidence seems to partially falsify our first theoretical proposition that labor success is caused by comprehensive campaigns. But is this judgment sustained by the fuzzy Philippine case if considered from the workplace collective's perspective claiming organizing and bargaining rights? While the first trade union failed to obtain recognition from management, an alternative trade union achieved recognition and collective agreement without conducting any global campaign! Given that the Turkey case seems to follow the core proposition presenting a comprehensive global campaign and a positive result, the core proposition of the theory seems to be corroborated positively, and so it does if the Philippine case is considered a failure taking the first legitimate union perspective. In sum, we need to dig deeper to try to resolve these contradicting findings and interpretations.

We start with the fuzzy case from the Philippines and end the case presentation with the most effective and time-efficient labor campaign from Turkey.

\section{The case of the Philippine industrial dispute}

Toyota Motor Corporation (TMC) returned to the Philippines in 1989 establishing the Toyota Motor Philippine Corporation (TMPC) assembling motor vehicles for the small Philippine market and organizing among other things a Labor-Management Council for consultation between management and labor represented by supervisors (Haruhi 2006). After several attempts to form an independent enterprise union, the Toyota Motor Philippine Corporation Workers Association (TMPCWA, the first union) was registered in 1998 as a union for rank-and-file employees claiming bargaining rights, which was accorded by the labor authorities in 2001 . When the management refused to engage with the union after union certification, the union staged a strike. The management put pressure on the Philippine authorities that ordered the union members back to work and the union followed the directive. Declaring the strike illegal, the management dismissed 233 employees out of approximately 1,450 (Shimizu 2003, 142) including union officials. Although the Supreme Court of the Philippines in 2003 declared that the management should start collective bargaining with the union, the management refused both to negotiate and to reinstate the dismissed employees.

The union mobilized and received support from civil society groups and labor organizations in the Philippines. It collaborated with the nongovernmental organization (NGO), Young Christian Workers of the Philippines, which supported the union during the first certification election process in 2000-01. It sought support from other unions and 
social movements from 2003-04, like 'Solidarity of Workers in Southern Tagalog Region' including the 'Alliance of Workers in the Enclave' and the Coalition of 'Auto Workers and Related Industries Against Imperialist Domination’ (Haruhi 2006, 267). This networking translated into a concerted local campaign by the union in collaboration with the Metal Workers Alliance of the Philippines. These organizations conducted demonstrations, such as the one in front of the Japanese Embassy in September 2006 protesting "the anti-worker policy of the Japanese transnational company, Toyota" (Wad \& Tackney 2011).

The union not only mobilized supporters in the Philippines but took the campaign to Japan and complaint to the ILO and the International Metalworkers Federation (IMF) in 2003. In Japan the union was supported by an NGO, 'Support Group for TMPCWA,' including NGOs and alternative industrial union federations like the All Japan Shipbuilding and Engineering Union to which the union became affiliated in 2004 in an attempt to pressure Toyota into direct negotiations. A complaint was filed with the OECD National Contact Point-Japan. Such contact points were established by OECD as multistakeholder forums administered nationally with the purpose of monitoring the OECD Code of Conduct for Multinational Enterprises. The complaint was buried by the Japanese agency and has never been processed properly.

The complaint to the ILO was processed, and ILO recommended the Philippine government to reconsider the case. The ILO support was a wake-up call for the global union, International Metalworkers Federation that tried to mediate via the Toyota Motor Corporation Union. When this failed, the global union initiated a worldwide campaign "Reinstate Them Now" in 2006, again without getting any concessions from Toyota. On the contrary, in 2010 four members of the Philippine union were dismissed. However, the global union later initiated meetings among its affiliates in the Philippines in order to build stronger union collaboration reducing the negative impact of high union fragmentation.

Meanwhile a second rank-and-file enterprise union, Toyota Motor Philippine Corporation Labor Organization (TMPCLO, the second union), was established in 2001 after the mass dismissals and joined the Labor-Management Council together with the supervisors' enterprise union. The second union achieved majority votes in a new, second certification process in 2006 in competition with the first union. This certification was conducted in accordance with Philippine industrial relations law allowing for replication of union certification after five years (Erickson et al. 2003), but it excluded the more than 200 dismissed members.

In sum, the first enterprise union lost the battle with Toyota, and a quarter of the rank-and-file workforce was expelled and substituted by new irregular and regular employees. A second union was formed and included in the labor-management institution, won the second rank-and-file union certification election, and concluded a collective agreement with the management. From a workforce perspective, the worker collective achieved union recognition through the second union and the first collective agreement with the employer. From the legitimate first union perspective, the member base was downsized and the workplace collective transformed by the employer. The campaign by the first union has so far been a failure as it has not obtained recognition from Toyota. The negative outcome for the first union and the positive one for the second union are generated after the first union conducted a semicomprehensive campaign mobilizing support from many corners and scales, except from TMC and its enterprise union that acknowledged the CLO as a legitimate and responsible union of the TMPC workers. 


\section{The case of the Malaysian industrial dispute}

The company, Euromedical Industries (or Euromedical), was established in 1975 as a joint venture between foreign majority and state minority capital in the Malaysian state of Kedah close to Penang with the purpose to produce rubber- and plastic-based medical equipment for export. Immediately, the predominantly female worker collective applied for unionization, but as per Malaysian industrial relations legislation the authorities should approve the match between unions' jurisdiction and the workplace in question. Only in 1983 the National Union of Employees in Companies Manufacturing Rubber Products (NUECMRP, or Rubber Union) was recognized as the appropriate union and was thus entitled to claim majority membership support and call the employer for collective bargaining. This process dragged on due to legal disputes in the industrial relations system and the civil court system and to management's attempt to form an in-house union. When the authorities finally certified the Rubber Union as the single representative industrial union of Euromedical's rank-and-file workforce in 1993, the management successfully challenged the authorities' decision in the local civil court only to be followed by an appeal to the Court of Appeal by the authorities in alliance with the Rubber Union which was won in 1998. This outcome made the management file the case with the Federal Court before losing definitively in 2004. The management recognized the Rubber Union in 2005 and the first collective agreement was concluded for the three years 2007-2010.

Meanwhile Euromedical had shifted majority ownership among foreign corporations several times. In 1998 the largest Danish TNC, APM-Maersk, acquired a controlling share in its attempt to build a strong medical product division, Maersk Medical. Soon after, the APM-Maersk Group decided anyway to divest its manufacturing activities, focusing its core business on container shipping and oil/gas exploration, while keeping a strong interest in retail business. The Euromedical management did not change policy on the issue of union recognition, and by the end of 2001 it decided to cancel the traditional annual bonus due to slack business performance. The workers started a wild-cat strike in protest and the management retaliated by suspending dozens of workers and finally dismissing four union activists in 2002.

Given the Danish variety of coordinated market capitalism building on strong national industrial relations system of collective organizing, collective bargaining, and conflict resolution, union harassment was unexpected by the management of a Danishcontrolled affiliate with cordial relations to unions in Denmark. But more was in the pipeline. Danish unionists had visited Euromedical and met Malaysian union activists and workers in 2001 before the wild-cat strike, and they had tried to persuade the local management and the Maersk Medical division headquarters in Denmark to recognize the Rubber Union and conclude a collective agreement, in vain. When they were informed about the issues of annual bonus, strike, suspension, and dismissals, the local chapter of the Danish labor NGO (Labor Movement's International Forum) initiated a campaign ("The Mouse and the Elephant") to challenge APM-Maersk's violations of international labor rights in Malaysia.

The labor NGO took responsibility for mobilizing Danish support for the Malaysian workers after consulting the relevant trade unions, the Danish Federation of Female Workers and the peak labor union, Danish LO. The Danish unions would not risk jeopardizing their good relationship with APM-Maersk in Denmark on behalf of 
"some women in Malaysia" (Wad 2007, 56), but they supported the campaign financially and logistically. The campaign used traditional methods of street agitation, flyers, posters, newspaper information, as well as innovative methods like shareholder activism at the annual APM-Maersk general meeting and complaining to the new OECD National Contact Point-Denmark. The OECD complaint was the first one launched in Denmark and first to be blamed was the Danish corporate giant which took pride in its corporate reputation. Tense interaction followed between the local OECD agency, Maersk Medical, union activists, and labor politicians, and mistaken use of union notepaper for the local labor NGO's complaint to the OECD Contact Point increased the suspicion of APM-Maersk that the Danish unions supported the initiative.

APM-Maersk divested its shares in Euromedical in 2002. The company was sold together with the rest of the Maersk Medical division to the Swedish-controlled private equity company, Nordic Capital, that wanted to create a strong medical group (Unomedical headquartered in Denmark) before spinning it off after some years. The OECD case was transferred to the new owner that promised to follow the result of Malaysian legal process. When it came in 2004 and sustained the right of Rubber Union to unionize and bargain for the Euromedical workers, Unomedical dragged its feet but was finally persuaded by the Malaysian authorities and the Rubber Union to comply with the court's award.

In sum, the successful outcome of the industrial dispute was not primarily or only determined by the international campaign of the Danish labor NGO. It took 30 years getting the labor right approved! The result was secured by using the Malaysian industrial system and civil judiciary that finally implemented the legislation correctly and approved the claim of the Malaysian industrial relations authorities and the industrial union against the claim of transnational capital and despite workers resorting to illegal industrial action in 2001. However, the Danish labor NGO campaign secured that the new corporation in charge of Euromedical did comply with the OECD code of conduct for TNCs instead of divesting its production in Malaysia as the former TNC did. The Danish trade unions did not intervene directly in favor of the Malaysian union. Instead, the peak union of LO closed down the labor NGO in 2006 claiming that it wanted to strengthen its international solidarity work. In reality, it eliminated an institution that enabled labor activists to engage in transnational union collaboration and empowerment and thus Danish LO reduced the space open for international grassroots solidarity work in Denmark!

\section{The case of the Sri Lankan industrial dispute}

At the time of the industrial dispute in Sri Lanka the Swedish TNC, Trelleborg AB, operated in 40 countries with a labor force of 22,000 employees (Egels-Zandén \& Hyllman 2007). It was a global producer of industrial rubber items specialized in advanced polymer technology serving customers in aerospace, agriculture, automotive, transportation, and oil \& gas worldwide. It had two tire plants in Sri Lanka with nearly 700 employees, of which 250 were employed in the Biyagama Free Trade Zone where the dispute evolved. The Sri Lanka facility became Trelleborg's global center for solid industrial tires during the 2000s (www.Trelleborg.com/en/The-Group/History/ accessed March 21, 2013). 
The Swedish TNC was guided by a code of conduct that secured minimum labor rights at its transplants around the world, including core international labor rights. Thus, it should be a matter of routine to recognize a new union organized in 2003 by employees at the Biyagama Free Trade Zone plant and affiliated to the Free Trade Zones \& General Services Employees Union (FTZ\&GSEU) that was constituted as a politically independent industrial union around the free trade zone, counted around 15,000 members, and affiliated to the global union, International Textile, Garment and Leather Workers' Federation (ITGLWF). Yet, the local union's communication to the Trelleborg subsidiary management in 2004 fell on deaf ears. The union then approached its global union as well as the Swedish Industrial Workers' Union (SIWU) and the NGO, Swedish Clean Clothes Campaign (SCCC). A meeting was held in the free trade zone between the Sri Lanka industrial union and the Swedish corporation mediated by the labor authority of the free trade zone where the local management representative agreed to the recognition claim, but without taking any action. On the contrary, the management tried to form an Employees' Committee to circumvent the new union, but workers refused to join.

Months later in early 2005, the regional management of Trelleborg's Asian activities informed the local union and the industrial union that Trelleborg would not recognize the industrial union. Management threatened to exit Sri Lanka because the industrial union in its view had forced companies to close factories and relocate to China. A strike broke out when the bonus system was changed excluding irregular workers from the bonus wage. With the strike the global union intervened complaining to the Swedish headquarters and demanding that the lockout following the strike be terminated. The global union threatened to bring the case to the OECD for breaching the OECD code of conduct for multinationals. The Swedish industrial union contacted Trelleborg headquarters to make them comply with their corporate code of conduct. After a week, the subsidiary management in Sri Lanka called the workers back to work while suspending 18 employees that were also local union activists. Workers refused to resume work in this situation. Once again the Swedish TNC backtracked and allowed all workers to return to work if they signed a letter of apology, yet under the condition that the letter would have no implication whatsoever. The local union agreed to these terms believing that the management with the deal recognized the union.

In sum, the concerted international campaign of the local unions, the global union, and the Swedish unions made the Swedish TNC comply with its own code of conduct framed by the OECD code of conduct for TNCs. The global union had endorsed the Global Framework Agreement approach in 2001 and entered one with a Swedish TNC, IKEA (Miller 2004), but it had not concluded one with Trelleborg at the time of the industrial dispute in Sri Lanka. The global union had in fact started criticizing the code of conduct mechanism which had gained significant support by NGOs and international NGOs during the 1990s and translated, for example, the Swedish Clean Clothes Campaign from 1996 with the support of Swedish NGOs, national industrial unions, and garment retailers like Hennes \& Mauritz (Ählström \& Egels-Zandén 2008; Egels-Zandén \& Hyllman 2006). The participating Swedish unions withdrew from the so-called 'DressCode' in 2002 which effectively stopped the multistakeholder TNC code of conduct project in Sweden.

The campaign of the global union network against Trelleborg in Sri Lanka can be seen as a semicomprehensive campaign because it included a wild-cat strike in the focal company in the free trade zone of Sri Lanka and a global campaign against the corporate 
HQs by the Global Union Federation and the home country industrial union. But the campaign did not target the TNCs' growth and profit centers through consumer campaigns for labor rights compliance boycotting Trelleborg's products. Trelleborg had also focused its business on industrial rubber and polymer product manufacturing with few linkages to the global textile and garment industry. However, the Sri Lanka-based factories were key to one of Trelleborg's global businesses, thus a corporate growth center, and Trelleborg strengthened its own code of conduct policy joining the UN Global Compact in 2007.

\section{The case of the Turkish industrial dispute}

Turkey-based die and metal sheet maker, Fontana Pietro Kalip, is a subsidiary of Italian TNC, Fontana Pietro, that is an engineering, die, and metal sheet corporation with two production plants in Italy and Turkey at the time of the industrial dispute in 2012-13 (www.Fontana-group.com; accessed March 17, 2013). The Italian TNC is a component supplier of dies and metal sheets to the global automotive industry with key customers among the three German auto TNCs, BMW, Daimler Benz, and Volkswagen and Italian Ferrari. The Turkish subsidiary employed around 230 workers, of which Turkish industrial union, Birlesik Metal Is (the United Metal Workers' Union), had unionized the majority in 2012 and applied the authorities for recognition as the legitimate union for Fontana Pietro Kalip workers. Discovering the organizing drive, the management dismissed four local union leaders and filed a court case against the Ministry of Labor. The Turkish industrial union informed their global union federation, the newly formed IndustriALL, which included the global unions of metal workers and garment workers. The new global union called upon the Fontana Pietro Kalip management to reinstate the dismissed unionists and stop harassing the workers and recognize the union. IndustriALL also informed its two Italian metal industrial unions, FIM-CISL and FIOM-CGIL, that had members at the TNC's home plant, and they complained to the Italian HQs. Finally, IndustriALL called upon assistance from their union members in the three Works Councils at BMW, Daimler, and Volkswagen to intervene based upon the Global Framework Agreements concluded between IndustriALL and the three German automobile corporations. Then, the Turkish subsidiary of Fontana Pietro withdrew its court case against the Turkish ministry and settled to recognize the union (IndustriALL Feb 28, 2013).

In sum, the mobilization of support by the Turkish industrial union from its global union federation that again coordinated a campaign to pressure the Italian subsidiary and HQs directly and indirectly through its key customers seemed to be enough to change the policy of the Italian TNC and comply with claim of the Turkish industrial union and the decision of the Turkish ministry. Thus, mobilizing its global union network and targeting both the TNC HQs and key industrial customers of the TNC, the Turkish union and its allied unions conducted a comprehensive campaign and accomplished its objective without resorting to industrial actions like strikes or boycotts.

\section{Summing up}

In the three clearly successful organizing campaigns, the key local actors were industrial unions and local workplace collectives, yet the type of industry varied (see Table 1). In 
Table I Four cases of industrial disputes about unionizing and collective bargaining in foreign-affiliated factories in the Global South.

\begin{tabular}{|c|c|c|c|c|}
\hline $\begin{array}{l}\text { Location } \\
\text { of dispute }\end{array}$ & $\begin{array}{l}\text { Philippines } \\
\text { 200I-(2006) }\end{array}$ & $\begin{array}{l}\text { Malaysia } \\
\text { 1983-2006 } \\
(2001-2006)\end{array}$ & $\begin{array}{l}\text { Sri Lanka } \\
\text { 2003-2005 }\end{array}$ & $\begin{array}{l}\text { Turkey } \\
2012-2013\end{array}$ \\
\hline Industry & Automotive & Medical equipment & Chemical, diverse & Automotive \\
\hline $\begin{array}{l}\text { Location of } \\
\text { TNC HQs }\end{array}$ & Japan & Denmark & Sweden & Italy \\
\hline $\begin{array}{l}\text { Foreign/ } \\
\text { total } \\
\text { workforce }\end{array}$ & $\begin{array}{l}\text { Toyota Motor } \\
\text { Corporation: } \\
\text { Approx. } 50 \%\end{array}$ & $\begin{array}{l}\text { Maersk Medical: } \\
\text { Approx. >50\% (2000). } \\
\text { APM-M <50\% approx. }\end{array}$ & $\begin{array}{l}\text { Trelleborg AB: } \\
\text { Approx. 50\% }\end{array}$ & $\begin{array}{l}\text { Fontana Pietro } \\
\text { Group: Approx. } \\
50 \%\end{array}$ \\
\hline $\begin{array}{l}\text { Dispute } \\
\text { content }\end{array}$ & $\begin{array}{l}\text { Local enterprise } \\
\text { union organizing } \\
\text { TNC control-led } \\
\text { joint venture }\end{array}$ & $\begin{array}{l}\text { Industrial union } \\
\text { organizing TNC- } \\
\text { controlled joint } \\
\text { venture }\end{array}$ & $\begin{array}{l}\text { Industrial union } \\
\text { organizing TNC } \\
\text { subsidiary }\end{array}$ & $\begin{array}{l}\text { Industrial union } \\
\text { organizing TNC } \\
\text { subsidiary }\end{array}$ \\
\hline $\begin{array}{l}\text { Global } \\
\text { campaign }\end{array}$ & $\begin{array}{l}\text { Semicomprehensive } \\
\text { multilevel union } \\
\text { and NGO campaign } \\
\text { incl. OECD NCP. } \\
\text { Traditional local } \\
\text { legal strike and } \\
\text { boycott }\end{array}$ & $\begin{array}{l}\text { Semicomprehensive } \\
\text { local union and foreign } \\
\text { NGO campaign incl. } \\
\text { OECD NCP. Tradi- } \\
\text { tional wild-cat strike } \\
\text { and boycott }\end{array}$ & $\begin{array}{l}\text { Semicomprehen- } \\
\text { sive campaign at } \\
\text { multilevels by unions } \\
\text { and foreign NGO. } \\
\text { Wild-cat traditional } \\
\text { strike hits growth } \\
\text { center }\end{array}$ & $\begin{array}{l}\text { Comprehensive } \\
\text { campaign at mul- } \\
\text { tilevels of unions } \\
\text { targeting key } \\
\text { industrial } \\
\text { customers }\end{array}$ \\
\hline $\begin{array}{l}\text { GVC points } \\
\text { of leverage }\end{array}$ & $\begin{array}{l}\text { TMC'sTPS key } \\
\text { to profitability, no } \\
\text { CoC. TMC's Japan, } \\
\text { Thailand, China, } \\
\text { United States or } \\
\text { European Union } \\
\text { operations not } \\
\text { targeted nor hit } \\
\text { lacking transplant } \\
\text { labor capacity. } \\
\text { TAP not key to } \\
\text { any core TMC } \\
\text { centers }\end{array}$ & $\begin{array}{l}\text { TNC 1998-2002 } \\
\text { not incl. Euromedical } \\
\text { in growth plan, or as } \\
\text { profit center. TNC's } \\
\text { core growth to be in } \\
\text { oil \& gas, shipping. } \\
\text { No CoC. Cash cow } \\
\text { of Danish retail } \\
\text { not identified by } \\
\text { campaigners }\end{array}$ & $\begin{array}{l}\text { TNC CoC policy, } \\
\text { but union aspect } \\
\text { weakly enforced. } \\
\text { Host country } \\
\text { subsidiary growth } \\
\text { center (and } \\
\text { profitable?). }\end{array}$ & $\begin{array}{l}\text { TNC had no } \\
\text { CoC. Host plant } \\
\text { probably key profit } \\
\text { and growth center }\end{array}$ \\
\hline $\begin{array}{l}\text { Institutional } \\
\text { points of } \\
\text { leverage }\end{array}$ & $\begin{array}{l}\text { Philippine IR law, } \\
\text { ILO, OECD NCP } \\
\text { inactive. } \\
\text { Weak Japan NGO. } \\
\text { No GFA with TMC. }\end{array}$ & $\begin{array}{l}\text { Malaysian IR law and } \\
\text { higher courts. OECD } \\
\text { NCP activated. No } \\
\text { GFA with APM-Maersk }\end{array}$ & $\begin{array}{l}\text { Sri Lankan IR law } \\
\text { favors union claim. } \\
\text { FTZ authority me- } \\
\text { diator. GUF threats } \\
\text { using OECD CoC. } \\
\text { Swedish NGO } \\
\text { irrelevant }\end{array}$ & $\begin{array}{l}\text { Turkish IR law } \\
\text { allowed organizing, } \\
\text { union certified. } \\
\text { No involvement of } \\
\text { OECD or NGOs }\end{array}$ \\
\hline
\end{tabular}




\begin{tabular}{|c|c|c|c|c|}
\hline $\begin{array}{l}\text { Global } \\
\text { labor } \\
\text { network } \\
\text { capacity }\end{array}$ & $\begin{array}{l}\text { No TMC home } \\
\text { unions or IMF-Japan } \\
\text { support for CWA. } \\
\text { Support from IMF, } \\
\text { weak Japan industry } \\
\text { union }\end{array}$ & $\begin{array}{l}\text { No active support by } \\
\text { APM-Maersk Danish } \\
\text { unions to Rubber } \\
\text { Union. Danish labor } \\
\text { NGO chapter in } \\
\text { support }\end{array}$ & $\begin{array}{l}\text { Home country } \\
\text { industrial union } \\
\text { and GUF active } \\
\text { supporters }\end{array}$ & $\begin{array}{l}\text { No GFA, but active } \\
\text { GUF had GFA with } \\
\text { key TNC custom- } \\
\text { ers, their unions, } \\
\text { and EWCs }\end{array}$ \\
\hline Outcome & $\begin{array}{l}\text { Failure (CWA) } \\
\text { yet success (CLO) } \\
\text { after transformed } \\
\text { workforce gained } \\
\text { recognition and } \\
\text { CBA after five years. } \\
\text { Dismissal cases } \\
\text { unsolved }\end{array}$ & $\begin{array}{l}\text { Success by worker col- } \\
\text { lective after } 30 \text { years } \\
\text { campaign, last two } \\
\text { decades with industrial } \\
\text { union. Dismissal case } \\
\text { solved out of court }\end{array}$ & $\begin{array}{l}\text { Success after I } 1 / 2 \\
\text { year for industrial } \\
\text { union. Union recog- } \\
\text { nized and dismissed } \\
\text { workers returned }\end{array}$ & $\begin{array}{l}\text { Success after } 1 / 2 \\
\text { year for industrial } \\
\text { union recognition. } \\
\text { Dismissed workers } \\
\text { returned }\end{array}$ \\
\hline
\end{tabular}

HQs = corporate headquarters. OECD NCP = OECD National Contact Point. CoC = Code of Conduct for TNCs. GFA = Global Framework Agreement. FTZ = Free Trade Zone. GUF = Global Union Federation (Global Union). $\mathbb{R}=$ Industrial Relations. IMF = International Metalworkers Federation. EWC = European Works Council. CWA = First union in Toyota Motor Philippine Corporation. CLO = Second union in Toyota Motor Philippine Corporation.

these corporations the workforce of varying size had been internationalized to the point where around half of the corporate workforce were located in foreign countries relative to the HQs' home country. Depending on the point of departure, the outcome of the dispute between the workers and the management at the Toyota assembling company in the Philippines is a failure (the first union) or a success (the second union), and from the workforce it must at last be considered a successful compromise facing one of the global automotive industry's top 3 corporations during the 2000s.

The labor campaigns undertaken did all involve cross-border collaboration and support, but the campaigns varied in regard to activities targeting global corporate centers of profit or growth. Thus, in the Philippines and Malaysia, the direct industrial actions (strike) or legal actions did not hurt any growth or profit centers, and when the global union was mobilized in the Philippine case it was unable to engage the core home country unions on the side of the first union in the Philippines. In Sri Lanka and Turkey, on the contrary, global unions and affiliated industrial unions in the home country of the TNCs were mobilized and intervened successfully. Only the Turkey-focused campaign can be classified as a comprehensive campaign because it targeted vulnerable relationships to key customers. Yet, the Sri Lanka-focused campaign did turn out to be a comprehensive campaign in practice because the traditional strike hit a corporate growth center.

All in all, it is difficult to find a clear common social mechanism that explains the more or less effective and efficient outcomes by way of the labor campaign undertaken. In fact, both comprehensive and semicomprehensive campaigns elicited positive results. As claimed by Wills (1998), globalization does indeed open new opportunities for transnational union organizing and collective bargaining instead of only closing spaces for effective labor action. The question is how and why! 


\section{Comparative case analysis and interpretation}

Following the Global Labor Network approach, we shall link the workplace industrial dispute about union organizing and collective bargaining with two key forces. The first one is a potentially effective labor strategy based on the analysis of weak spots in the global value chains of the controlling TNC together with the embeddedness of the global corporate network in political or nonpolitical institutions. The second one is the match or mismatch of labor strategic power between an effective strategy and the capability of the focal worker collective/union and their alliance/coalition/network with labor and nonlabor partners as played out in the global labor campaign. Whether or not an effective labor strategy is available is a question of theoretical analysis of the actual and potential global labor networks relative to the existing corporate network, and whether it is implemented effectively and efficiently is a question of empirical analysis of the actual labor campaign relative to its theoretically established space of social mechanisms for potential collective action.

Let us start with the two cases that at first sight seem to validate the core proposition of the theory negatively (Philippines case as a failure) and positively (Turkey case of success). They are both situated in the global automotive industry, but the focal capitallabor disputes are tied to a Northeast Asian motor vehicle producer (Toyota) and its operations in Southeast Asian and a European automotive component supplier (Fontana Pietro) with its foreign operations in the Middle East, respectively.

Regarding the Philippine case, there is an obvious mismatch between the power of the globally founded, wealthy, and locally well-connected Japanese automaker and the power of its labor counterpart, that is a new and independent enterprise union based at Toyota's affiliated plant in the Philippines and serving a market that had no strategic significance for Toyota as a profit or growth center in Southeast Asia in the early 2000s (Doner \& Wad forthcoming). The Philippine enterprise union was supported by a Christian NGO but it realized after the clash with Toyota's local management and its loss of its workplace base through mass dismissals that it had to ally with other metal workers' unions and the global union federation. Through its Christian network the dispute was transferred to Japan and carried on by Japanese NGOs and industrial unions. Its Japanese allies were unable to challenge Toyota in its home country through its enterprise union or the federation of enterprise unions in the automotive industry. Even the new OECD institution was not publicly pushed to take action persuading Toyota to comply with the code of conduct of OECD. The global union only called for a reinstatement of dismissed workers of Toyota's affiliate in the Philippines and no direct industrial actions of solidarity were launched worldwide that could hit profit centers or growth centers in Thailand, China, Europe, or the United States. The Japanese metal workers' unions have a strong position in the global union and especially in the Asia-Pacific region. All in all, the labor campaign was semicomprehensive forming a global labor network, but this network was not including the key unions and worker collectives in Japan and around the world, nor did it target and hit Toyota's global growth or profit centers.

Yet the global campaign might anyway have impacted Toyota's union policy in the sense that corporation accepted an alternative enterprise union committed to responsible and participatory union engagement in the Philippine assembling company. It is contested whether this second union was independent of the management and aimed to form an industrial union, but this was anyway claimed by its local union network 
(Wad \& Tackney 2011). The second union's policy and practice was acceptable to Toyota and its home country enterprise union.

The global campaign of the first union could not effectuate its cause of reinstatement and union recognition, but ironically it opened up for a compromise. The enduring dispute could eventually tarnish Toyota's global reputation mediated by labor campaigning messages like 'No. 1 Union Busting Corporation.' A local solution was found as demanded by Toyota and its Japanese union. This solution complied with Philippine industrial relations law and the core international labor right at stake embodied in the second union and the concluded collective agreement. Whether any conceivable labor strategy could overcome Toyota's resistance to a union that is considered unfit for Toyota's participatory principles in the Toyota Production System is questionable. Even American unions have fought an uphill struggle to unionize Toyota's transplants in the United States. And the second enterprise union achieved its objectives without undertaking any global campaign but relating to domestic moderate metal workers' unions and Toyota's enterprise union! The conclusion is that no workers' union would had been recognized if it had not been for the international campaign initiated by the first legitimate enterprise union!

In the opposite end we have the Turkey case where the new and stronger global union (IndustriALL) was activated by the legally certified Turkish industrial union and coordinated a 'global' campaign that targeted the subsidiary's TNC HQs in Italy and key customers in Germany. The campaign was transmitted by the Italian and German industrial unions, and it made use of the institutions of Global Framework Agreements and Works Councils to pressure the Italian TNCs' value chain downstream. This campaign worked very efficiently and effectively securing a positive outcome in terms of union recognition within half a year. The campaign can be said to be comprehensive at a global level bridging the North-South divide, and it delivered a prolabor result fast, thus testifying to the validity of the core propositions of the Global Labor Network theory.

The two other clear-cut successes of semicomprehensive campaigns require further analysis and eventual modification or deepening of the theory. These cases comprise TNC-controlled firms in industrial rubber/polymer product business with different markets (health services versus heavy transport equipment). The Malaysia case of Euromedical was for nearly 30 years a failure, but it turned out to become a success when the dispute was internationalized and the legal institutional process came to an end in Malaysia. The question is whether the domestic legal strategy of the Malaysian industrial union proved effective independent of international union support, which would falsify the theory like the 'second union win' in the Philippines. This key question can be answered by addressing two subquestions: first, why did the labor authorities and the judiciary approve the quest of the Rubber Union in a political context of antiunionism? And second, why did the TNC stay on in Malaysia instead of divesting and leaving the country?

The hypothesis is that the central Malaysian state and the Rubber Union were forced into an alliance because the union's claim was right legally speaking and it was accorded legality by the authorities after two decades of legal battles. At the local state level of the confederation of the Malaysian state, the industrial relations authorities and judiciary might have given priority to foreign and local capital interests located in the area. When the central authorities finally agreed to the union certification issue, the authorities (and the union) were challenged by the TNC in the civil court system. After nearly 10 years, 
the civil court system sided with the state and the union. The overruling of the TNC's interest might have been facilitated not only by the legal validity of the union claim but also by the fact that the medical equipment industry was not a strategic important sector relative to the electronics export industry. Thus, the state did not incur (risks of) huge losses by foreign divestments. This risk had been high in the US-dominated electronics industry where the government did not allow the formation of a national industrial union of electronics workers since the early 1970s. The government finally agreed to legalize enterprise unions in the late 1980s and regional-based industrial unions in 2010, but not yet industrial unions (Wad 2012a).

But why did the TNC comply with the award by the Federal Court and finally recognized the industrial union's claim of representation? The controlling TNC of Euromedical, the Nordic private equity company, did at the time of the ultimate judgment (2004) take a medium-term strategic growth interest in the Malaysian joint venture. This contrasted the former 'owner,' APM-Maersk, which decided divesting its manufacturing activities, including the Malaysian joint venture. Moreover, APM-Maersk divested before the final award was given, and before the OECD code of conduct process had come to its conclusion. The new 'owner' agreed to follow the final judgment of the Malaysian judiciary, and did so in due time, but both corporations could have solved the issue out of court and accepted the claim of the Rubber Union. In sum, there were strategic corporate reasons for compliance in the end.

Yet, the prolonged postponement of the core labor right was equal to the denial of this right for three decades. The victory of the Rubber Union and the Danish Labor NGO was a pyrrhic victory. It cost the Rubber Union a lot of money, and it probably added to the closing down of the Danish Labor NGO by its union owners. Only an extremely resilient workforce of mostly unskilled women carried the struggle to its successful termination. Some even lost their jobs and were only compensated out of court after several years of negotiations. Along the way the industrial union underwent union policy battles and shift of leadership which reflected a learning process and dynamic capabilities of various labor groups. When a grassroots-oriented leadership was in power the union pursued a more international policy engaging the Danish labor NGO, and this relationship continued at grassroots levels when union leadership returned to the more legalistic minded persons.

Comparing the Euromedical case story in Malaysia with the Trelleborg incident in Sri Lanka, the industrial dispute was resolved much faster in Sri Lanka than in Malaysia. In Malaysia, APM-Maersk did not comply at all but preferred to exit contrary to Trelleborg in Sri Lanka. One difference in corporate policy relates to the corporate stance on the OECD code of conduct. APM-Maersk did not have a policy following the OECD institution at that time. The Danish corporation only pursued a policy of Corporate Citizenship which is more about complying with the laws of the home and host countries and support society in an altruistic way. After the Malaysian incident-and other international incidents in Central America, Africa, and China-APM-Maersk decided to develop a corporate social responsibility policy and organizational capability in the wake of internal changes of corporate governance at top management level.

In the Sri Lanka case, the Swedish TNC, Trelleborg AB, had a code of conduct policy which became the key point of attack by the Sri Lankan and the Swedish industrial unions and the global union. The Code of Conduct policy was not made redundant by Sri Lankan industrial relations law. Yet, the TNC headquarters did not comply 
immediately at the local and macroregional level. Corporate compliance took a weeklong strike and lockout in the Sri Lankan free trade zone. The Swedish TNC was thus by mismanagement hit directly in one of its core growth centers that supplied global industries and customers. It was simply too costly to continue a dispute that contradicted its strategic business interests, its declared labor policy (for home consumption in Sweden), and the legislation in the host country of operation!

The demand of the Sri Lankan industrial union was accepted within a time span of $1 \frac{1}{2}$ years. The result was effectuated by the combined global intervention of the global union federation, the TNC home country industrial union, and the local pressure by the host country union and the worker collective initiating a classic industrial action. The campaign of the global labor network was semicomprehensive in the sense that it did mobilize locally and globally but it did not target profit or growth centers of the TNC outside Sri Lanka. The Swedish TNC had rhetorically subscribed to the international labor rights of ILO, including the right to organize and bargain collectively, but it had not strictly complied with this policy in developing countries. Thus, it faced loss of corporate reputation, public pressure by OECD and the Swedish public, and increasing problems servicing global customers. The dispute could even worsen if it did not resolve the strike in Sri Lanka and if the dispute triggered international sympathy actions coordinated by the global union.

Summing up, we can say that a comprehensive campaign can be highly effective and efficient (Turkey case). However, prolabor results can be achieved fast even with semicomprehensive campaigns that emerge out of industrial contradictions in a particular growth or profit center of a TNC (Sri Lanka case). The paradoxical prolabor outcomes in Malaysia and the Philippines in the wake of semicomprehensive campaigns indicate that the fit between a labor organization's code of conduct and its corporate counterpart's production system may enable a compromise allowing for labor organizing and collective bargaining (the Philippines), while the Malaysian outcome was available after enduring legal processing in an industry of marginal importance to the core political and economic elite in Malaysia.

Thus, globalization seems to open new avenues for international labor networking and campaigning that can provide positive results in terms of workplace organizing of TNC affiliates in developing countries. The combined forces of cross-border labor networking based on local workplace decisiveness and national industrial union support can nowadays link up with global unions and/or industrial unions and works councils in TNC home countries. This joined pressure can push TNC management to comply with global framework agreements or publicly declared TNC own codes of conduct, OECD standards, or core ILO international labor rights.

On the other hand, cross-border horizontal workplace networking between worker collectives did not seem to affect the outcomes, maybe except in the Philippine case. Strong horizontal intra-corporate labor networks did not exist in the four cases! Why? Three explanations are possible. Firstly, corporate employment structures of the focal TNCs were less internationalized than expected. A fairly equal mix of 'home' and 'foreign' employees makes the home country workforce outnumber other countries' specific workforces. This feature may weaken the overall inclination of employees to form and develop intra-corporate cross-border workplace labor networks.

Secondly, as argued by Schiller (2013, 272-274), the strengths of the home country unions in the Global North determine the level of international solidarity. If the 
Northern unions can govern their home affairs pretty well, they will not necessarily encourage their member unions and worker collectives in direct North-South solidarity actions as seen in the cases from Denmark and Japan. They may allow union-based labor NGOs to carry out international solidarity work, but such NGO platforms may also get out of central union control and union leaders will often react downgrading or abandoning them in times of union problems (Danish case). Union hierarchy is sustained.

Thirdly, trade unions have been constituted as national organizations, and they have over time built an international network that is supposed to handle cross-border issues. This formalized international union collaboration has been strengthened in the postCold War era with the merger of union confederations and international trade secretariats. Global unions have also promoted global framework agreements with TNCs as a means to secure core international labor rights. The drawback is that this progress in global union bargaining power is primarily recognized among European TNCs based in countries with coordinated market systems. Path dependence prevails.

\section{Conclusion and limitations}

The main question addressed in the paper is how labor can leverage effective power against management of global corporate networks? This question was split into two subquestions and analyses, one focusing on theory development, the other on empirical validation and theory adjustment. In order to conclude retroductively we combine the results of these two kinds of analysis in the following way.

A Global Labor Network perspective was theoretically outlined that can explicate strategic labor power countering global corporate networks and pressuring corporate decision-makers to comply with labor objectives-at least as long as the demands do not threaten corporate strategy for global profitability. The theory of Global Labor Network is eclectic based on four propositions from the extant literature that is integrated in a general proposition about union strategic power in global corporate network. The theory can now be qualified.

Comprehensive campaigning can be sufficient to create the wanted outcome (Turkey case), but it is not necessary in the sense that semicomprehensive campaigns can also accomplish the objective (cases of Malaysia, Philippines, Sri Lanka). Labor campaigning is not always informed by a global labor perspective and thus it may overlook strategic opportunities mobilizing and leveraging labor power at weak positions of the corporate counterpart. Although the Danish labor NGO used innovative methods, it did not realize that the retail company of APM-Maersk was a cash cow that could be targeted through a labor NGO-staged consumer boycott by Danish consumers.

The learning process of labor campaigning is important as successful collective action often takes time and requires adjustments along the way. Companies and the focal workplace of the industrial dispute can shift position within corporate value chains due to international mergers and acquisitions. Such shifts can change the bargaining relations between labor and management in a prolabor direction when the workplace graduates from a redundant position to a growth position (Malaysia case) or vice versa (the Philippines). 
The lead firms of the global industry and value chain are important targets of crossborder labor action. Lead firms with code of conducts including international standards of labor rights are more responsive and vulnerable to international campaigns (Sri Lanka case) than other firms, although corporate reputation may matter as does domestic judiciary institutions (Malaysia and the Philippines). But lead firms will often neglect enabling international labor rights until they risk corporate reputation and profitability. Basically, labor faces employer decision-making, which ultimately depends on ownership and control in global corporate networks.

Along the process of campaigning local worker collectives and domestic unions will have to scale up and down their campaign. Depending on the circumstances, local labor networks must become national and international in order to win, and they can also shift arena from industrial relations to civilian judiciaries and back again (Malaysia case). But scaling down and switching path of union approach can be necessary if the corporate counterpart will not bow to the union policy on labor-management relationship allowing space for a new union (Philippine case).

Finally, building and sustaining strategic labor power is a time-consuming process that must explore strategic opportunities in the global corporate network of operation on the one hand and secure labor capacity and dynamic capability through global labor networking on the other hand. However, this labor power must match the power of management in global corporate networks as well as the opportunities and obstacles of the political-judiciary system domestically (all four cases). In terms of time efficiency, the mobilization of global unions shortened the industrial conflict (cases of Philippines, Sri Lanka, and Turkey) relative to the dispute supported by a foreign labor NGO only (Malaysia case), but the most rapid effect was generated by the global union that had global framework agreements with important customers of the focal corporation (Turkey case). In the ineffective intervention by a global union (the Philippine case), no global framework agreement was in play with the key corporation. Nor did the corporation subscribe to OECD Codes of Conduct for compliance with core international labor standards. In the Sri Lanka case the opposite dynamic prevailed. Pressure from the local workplace collective, its industrial union, and the relevant global union elicited TNC compliance. The TNC's international reputation was questioned due to its noncompliance with its own code of conduct. In the Malaysia case of 30 years of union denial no global union was mobilized, and the successful outcome relied on domestic legal and international voluntary institutions for labor rights compliance.

Thus, the overall conclusion is that the adequate combination of global labor capabilities and global labor strategizing into strategic labor power can match corporate power in a global market economy in many situations, but some may require radical changes of the worker collective and union policy (Philippine case). Comprehensive labor campaigns can do the job, and even semicomprehensive campaigns can deliver but less efficiently. Traditional campaigns may even be part of the equation if they hit vulnerable points of corporate growth, profit, or reputation. Surprisingly, transnational workplace labor networks have not been a strong component of the 'winning' formula in our cases. Prolabor results have primarily been achieved within a national or international union framework rooted in coordinated market economies. Yet, all our TNCs tried at first to avoid having their particular affiliates unionized!

The validity of the present analysis is limited in various ways. Firstly, the embryonic forms of global union networks of workplaces within particular global corporations 
have not been analyzed through primary data generation, and the most effective labor campaign is only partially researched (Turkey case). Secondly, the internal differences among labor groups across scale and time have been downplayed, although they may reflect learning processes among labor factions and constituencies (Philippine and Malaysia cases). Thirdly, the dynamic capabilities and strategies of global corporations to counter global labor campaigns have not been considered in any detail. Fourthly, the multiple-case comparison includes corporations in transition from national to transnational workforces with around $50 \%$ foreign employees. Finally, only 'positive' outcome cases are considered, not clearly negative ones. Case studies of transnationalized corporate workforces and industrial disputes including negative outcome cases should be included in future research aiming to assess the validity and appropriateness of the Global Labor Network approach to issues of international solidarity actions in the 21 st century.

\section{References}

Ählström, J. \& Egels-Zandén, N. (2008) 'The processes of defining corporate responsibility: a study of Swedish garment retailers' responsibility', Business Strategy and the Environment, 17: 230-244.

Bronfenbrenner, K. (2007) 'Introduction', pp. 1-15 in Bronfenbrenner, K. (Ed.) Global Unions. Challenging Transnational Capital Through Cross-Border Campaigns. Ithaca: Cornell University Press.

Castree, N. (2007) 'Labour geography: a work in progress', International Journal of Urban and Regional Research, 31(4): 853-862.

Coe, N. M., Dicken, P. \& Hess, M. (2008) 'Global production networks: realising the potential', Journal of Economic Geography, 8: 271-295.

Cumbers, A., Nativel, C. \& Routledge, P. (2008) 'Labour agency and union positionalities in global production networks', Journal of Economic Geography, 8: 369-387.

Denmark's Statistics (2013) News from DS, various issues. Databases sourced.

Dicken, P. (2011) Global Shift. Mapping the Changing Contours of the World Economy. London: Sage.

Doner, R. \& Wad, P. (forthcoming) 'Financial crises and automotive industry development in Southeast Asia', Journal of Contemporary Asia.

Egels-Zandén, N. \& Hyllman, P. (2006) 'Exploring the effects of union-NGO relationships on corporate responsibility: the case of the Swedish Clean Clothes Campaign', Journal of Business Ethics, 64: 303-316.

Egels-Zandén, N. \& Hyllman, P. (2007) ‘Evaluating strategies for negotiating workers’ rights in transnational corporations: the effects of codes of conduct and global agreements on workplace democracy', Journal of Business Ethics, 76: 207-223.

Erickson, C. L., et al. (2003) 'From core to periphery? Recent developments in employment relations in the Philippines', Industrial Relations, 42: 368-395.

Fontana Group (2013) home page, www.fontana-group.com, accessed March 17, 2013.

Haruhi, T. (2006) 'Toyota in the Philippines: Drive your dream or drive to the bottom?' pp. 247-271 in Chang, D. (Ed.) Labour in Globalising Asian Corporations: A Portrait of Struggle. Hong Kong: AMRC.

IMF (2006) "Reinstate Them Now!" campaign. IMF-newsletter. www.imfmetal.org/

IndustriALL (2013) Newsletter. Accessed Feb 28, 2013.

Juravich, T. (2007) 'Beating global capital: a framework and method for union strategic corporate research and campaigns', pp. 16-39 in Bronfenbrenner, K. (Ed.) Global Unions. 
Challenging Transnational Capital Through Cross-Border Campaigns. Ithaca: Cornell University Press.

Juravich, T. \& Bronfenbrenner, K. (1999) Ravenswood: The Steelworkers' Victory and the Revival of American Labor. Ithaca: Cornell University Press.

Juravich, T. \& Bronfenbrenner, K. (2003) 'Out of the ashes: the steelworkers' global campaign at Bridgestone/Firestone', pp. 249-268 in Cooke, W. (Ed.) Multinational Companies and Global Human Resource Strategies. Westport, CT: Quorum Books.

Miller, D. (2004) 'Negotiating international framework agreements in the global textile, garment and footwear sectors', Global Social Policy, 4(2): 215-239.

Pennings, P., et al. (1999) Doing Research in Political Science. An Introduction to Comparative Methods and Statistics. London: Sage.

Riisgaard, L. (2009) 'Global value chains, labor organization and private social standards: lessons from East African cut flower industries', World Development 37(2): 326-340.

Schiller, B. (2013) 'Toward new trade union solidarity? A discussion of renewal and solidarity’ (in Swedish), pp. 257-282 in Lindberg, I. \& Neergaard, A. (Eds.) Bortom horisonten. Fackets vägval i globaliseringens tid. Stockholm: Premiss förlag.

Shimizu, K. (2003) 'A maverick in the age of mega-mergers? Toyota's global strategies', pp. 119-143 in Freyssenet, M., et al. (Eds.) Globalization or Regionalization of the American and Asian Car Industry? Houndmills, Basingstoke: Palgrave Macmillan.

Stockhammer, E. (2012). 'Why Have Wage Shares Fallen? A Panel Analysis of the Determinants of Functional Income Distribution', Conditions of Work and Employment Series No. 35. Geneva: ILO.

UNCTAD (various years) World Investment Report. Geneva: UNCTAD.

Wad, P. (2000) 'Comparison in critical realist perspective (in Danish)', Dansk Sociologi, 11(3): 7-28.

Wad, P. (2007) “"Due diligence” at APM-Maersk. From Malaysian industrial dispute to Danish cross-border campaign', pp. 40-56 in Bronfenbrenner, K. (Ed.) Global Unions. Challenging Global Capital Through Cross-Border Campaigns. Ithaca, NY: ILR Press/Cornell University Press.

Wad, P. (2012a) 'Revitalising the Malaysian trade union movement-the case of the electronic industry', The Journal of Industrial Relations, 54(4): 494-509.

Wad, P. (2012b) 'Realistic science theory and critical realism' (in Danish), pp. 375-420 in Jacobsen, M. H., et al. (Eds.) Videnskabsteori i statskundskab, sociologi og forvaltning, København: Hans Reitzel.

Wad, P. (2013) 'Getting labour rights right at a foreign controlled company in Malaysia. A Global Labour Network perspective', Geoforum 44: 52-61.

Wad, P. \& Tackney, C. T. (2011) 'David takes on Goliath—the case of workplace labor agency at Toyota Motors Philippine Corporation'. Unpublished paper.

Weil, D. (2005) 'A strategic choice framework for union decision making', Working USA: The Journal of Labor and Society, 8: 327-347.

Wills, J. (1998) 'Taking on the CosmoCorps? Experiments in transnational labor organization', Economic Geography, 74: 111-130. 